\title{
Channels of Protection: Communication, Technology, and Asylum in Cairo, Egypt
}

\author{
Nora DANiELson
}

\begin{abstract}
Communication between service providers and refugees about services, legal processes, and rights helps shape refugees' experience of asylum but has, in Cairo, Egypt, been a source of misunderstandings and conflict. Based on qualitative pilot research, this paper explores the practices, challenges, and potentials of information technologies old and new in facilitating access to asylum in this southern city. Interviews with refugee and service providers and review of previous technology-based initiatives show that although service providers tend to rely on oral information transfer, other channels-print, phone, text messaging, websites, social media-hold significant capacity for growth. Existing practices and initiatives in Cairo demonstrate the potential for technology-based projects to overcome the geographic barriers of the urban setting and the range of literacy and languages in Cairo's refugee communities. However, service providers and refugees require further funding and institutional support if this potential is to be realized.
\end{abstract}

\section{Résumé}

La communication entre les services et les réfugiés au sujet des ressources, des processus juridiques et des droits influence l'expérience des réfugiés, mais au Caire, en Égypte, cet aspect a été une source de malentendus et de conflits. Basé sur une recherche qualitative pilote, cet article explore les pratiques, les défis et le potentiel des technologies de l'information, anciennes et nouvelles, dans la facilitation de l'accès à l'asile dans cette ville du sud. Les entretiens avec les réfugiés et les responsables des services, ainsi que l'examen de précédentes initiatives technologiques, montrent qu'alors que les services comptent toujours sur la transmission orale de l'information, d'autres moyens tels que l'imprimé, le téléphone, la messagerie texte, les sites web, et les réseaux sociaux, consistent en autant de possibilités significatives de développement. Les pratiques et les initiatives actuelles au Caire illustrent que les projets technologiques ont le potentiel de surmonter les barrières urbaines et la variété des langues et des degrés de littératie des communautés de réfugiés du Caire. Toutefois, les organisations et les réfugiés ont besoin de davantage de subventions et de soutien institutionnel pour réaliser ce potentiel.

\section{Introduction}

Most of the world's refugees live in their region of origin, and more than half live in urban centres, where their period of asylum often lasts many years. The experiences of forced migrants in cities in the global south are shaped by intersecting stressors and constraints, many of which are impervious to change. This paper examines one set which, it argues, is neither intractable nor insignificant: the channels of communication through which humanitarian and nongovernmental organizations communicate with refugee communities $^{1}$ about rights, processes, and services available through refugee or asylum seeker status.

Taking as a case study one of the world's major refugeehosting cities-Cairo, Egypt-this paper outlines the findings of a 2011-12 qualitative pilot study of the changing technologies of service provider outreach to refugee communities. First, the paper shows that communication and information about asylum in Cairo has significant 
psychosocial, service provision, and protection impacts. Second, the channels and technologies that service providers use to communicate asylum-related information differ in reach, efficacy, and ease of use for both service providers and refugee communities. Third, evidence of contextual barriers, population diversity, and local use and interest in new technologies by refugees and service providers highlights considerable need and capacity for the improvement of such communication. Setting out these findings in a context of rising global interest in innovation and technology, I argue that urban refugee community outreach is due greater attention and policy development than it currently receives.

\section{Background: Asylum in Cairo}

Egypt is one of the world's major hosts of urban refugees. At the start of 2013, more than 125,000 people were registered with the Egyptian office of the United Nations High Commissioner for Refugees (UNHCR), originating from Sudan, Syria, Iraq, Somalia, Eritrea, Ethiopia, amongst other countries. ${ }^{2}$ Until 2012, when UNHCR opened a camp in Saloum for people fleeing Libya, Egypt had no refugee camps. $^{3}$

Although forced migrants in Egypt live in Alexandria and smaller towns, this paper focuses on Cairo, where the majority reside. Greater Cairo is the largest city in both the Middle East and the African continent, and host to refugee communities throughout its densely populated neighbourhoods. ${ }^{4}$ As conflicts in the region shift and flare, new asylum seekers arrive in the city each year, ${ }^{5}$ others return to their countries of origin, and a minority move onward. But the majority of forced migrants in Cairo experience protracted asylum, some staying for more than a decade.

During their time in the city, forced migrants negotiate survival and aspirations within a challenging, restrictive set of national and international contexts. As signatory to the 1951 Refugee Convention, Egypt grants refugees the right to residence, legal recourse, and freedom of religion and movement. The government also ratified the Refugee Convention's 1967 Protocol, the 1969 Organization of African Unity Convention Governing the Specific Aspects of Refugee Problems in Africa, and some human rights conventions.

Yet the national context is characterized by insecurity that particularly impinges on refugee communities. Incidents of mistreatment by police have included raids, corruption, arbitrary arrest, violence, and harassment. ${ }^{6}$ Political upheaval since 2011 has led to increased crime, instability, and xenophobia. Violence and harassment towards women and visible minorities has also increased throughout the country. ${ }^{7}$
Though Egypt has long hosted refugee communities, it lacks a domestic legal framework for refugee protection. Since 1954, it has given the responsibility for asylum seeker registration and refugee status determination (RSD) processing to UNHCR. ${ }^{8}$ Its reservations on the 1951 Convention ${ }^{9}$ limit refugees' work opportunities, leaving most with no or little work, or risking jobs in the unregulated informal market. ${ }^{10}$ Forced migrants in Egypt face frequent discrimination alongside the challenge of working across social, cultural, and language differences. The country's widespread poverty and unemployment, worse since the 2011 revolution, further reduce livelihood options, and most live in poverty. ${ }^{11}$

Egypt's Convention reservations also restrict refugee access to health care and education, both of which are further complicated by overcrowded, underfunded institutions and exclusionary procedures. ${ }^{12}$ Such compounding restrictions and challenges make the local integration of forced migrants in Egypt "nearly always impossible."13

The experiences, support, and aspirations of forced migrants in Cairo are linked into wider geopolitical contexts, including international social and economic networks, diasporic migration patterns, and changing socioeconomic and political situations in home countries. Yet few options for onward movement are available even to those recognized as refugees. Tension between the hope for resettlement and its actual limits increase both uncertainty about future plans and frustration with present circumstances. Such problems have been raised at multiple demonstrations at the Cairo offices of the UNHCR over the last decade and have driven some to abandon Cairo as a place of asylum. ${ }^{14}$

Asylum in Cairo consists of several elements, variously provided, in what has been called "a system of diffuse responsibility." 15 First and foremost, asylum entails protection, which UNHCR holds as its core mandate. ${ }^{16}$ Protection refers primarily to the prevention of refoulement-the forcible return of refugees to their country of origin-but extends to other elements of safety, security, basic human rights, and access to legal recourse which UNHCR seeks to ensure. In rare instances, special protection needs can result in individual resettlement to a third country, which may be negotiated between UNHCR, the embassies of countries that directly resettle refugees from Cairo, and agencies such as the International Organization for Migration.

Additionally, refugees and asylum seekers in Cairo may access limited education, financial, material, legal, and health assistance. A range of state-run, community-based, religious, and international and local non-governmental organizations offer support services for refugee communities in Cairo. Eligibility requirements for programs on offer differ: some may be accessed only by individuals recognized 
by UNHCR, some by those who fit an organization's own definition of asylum seeker, and some by all members of a refugee national group.

The legal positions of forced migrants in Egypt depend on their recognition by UNHCR, which carries out all asylum seeker registration and RSD procedures. People who register with UNHCR and await the outcome of their case receive yellow cards that identify them as asylum seekers. Recognized refugees hold blue UNHCR-issued identity cards, and a small number of stateless people also register with the office. ${ }^{17}$ Some forced migrants do not register with UNHCR, and others continue to live in Cairo after their applications for status with UNHCR have been denied.

The way that service providers communicate and share information about these complex elements of asylum in Cairo is only one of many factors impacting their well-being and access to support. Yet for multiple reasons it is both salient and promising, as following sections will unfold.

\section{Communication Technologies in Urban Asylum: Current Research}

Increasing policy and academic attention has been paid to refugees in urban centres in countries both of first asylum and of resettlement, and to the ties they maintain across geographically dispersed social networks. New technologies are critical channels in transnational communication, and research has begun to examine their role in refugees' lives. Corporate and philanthropic interest in information and communication technology (ICT) initiatives aimed at social problems is high. The intersection of these strands is due greater attention, especially as refugee communities "increasingly live in cities rather than in camps, and are harder to reach."18

Growing recognition of the importance of refugees' input into effective urban policy has led to research into the channels of their participation. ${ }^{19}$ Yet there has been limited study of outward communication between service providers and populations of concern, although the topic arises repeatedly in reviews of UNHCR's urban refugee policy. ${ }^{20}$ UNHCR's urban policy names interaction with refugees and community orientation as key principles, ${ }^{21}$ but the content, approaches, and impacts of such interaction beyond faceto-face meetings remain largely unexamined. ${ }^{22}$ The community outreach efforts of single programs or organizations have been profiled, drawing attention to good practices. ${ }^{23}$ But in complex urban settings, information about asylum moves through multiple media and institutions. This paper offers an initial view into the role of information in urban asylum.

Research on technology and refugees has emerged as a growing field, populated primarily by studies of refugee mobile phone and Internet use in camps, detention centres, and resettlement countries, with less evidence from urban settings in the global south. ${ }^{24}$ Attention has focused on communication over distance, between refugees and their social networks in sending and receiving countries. The role of information technologies within countries of first asylum, and their cities, has been neglected. Since many of the world's refugees live in cities and have social ties to refugees in other settings, their assessments of access to and the importance of different technologies provide an interesting counterpoint to existing knowledge. In cities in the global south, questions of access and literacy are paramount, and communication channels may not necessarily use new technology. This paper contributes a preliminary exploration of how technologies of communication are used by and for refugees in one such setting.

Given growing attention to the significance of transnational social relations, refugee-related technology studies have thus far largely centred on communication between refugees. ${ }^{25}$ Communication between refugees and service providers raises a different set of questions about how information is delivered and received, given variations of culture, institution, power, language and literacy that it must negotiate. Initial studies profiling ICT interventions in refugee service provision-reflecting its growing significance in the humanitarian aid sector-have largely focused on single programs or on camp, resettlement, or emergency settings. ${ }^{26}$ How ICT might help in urban situations in the global south has yet to be examined in depth or breadth, although such use has been recommended. ${ }^{27}$ This paper draws together these areas of study to consider, through the case of one city, how expanded use of information and communication technologies might improve refugee experiences of urban asylum.

\section{Pilot Project Methods}

This paper considers findings of pilot research into refugee community outreach in Cairo. Three questions framed the study: First, how do service providers communicate with Cairo's refugee communities? Second, what capacities exist for the development of different information-sharing technologies? Third, what barriers complicate access to asylum information in the city?

Carried out between July 2011 and March 2012, the project was first conceived in 2006 during work on two collaborative projects in Cairo ${ }^{28}$ and developed through research into asylum in Cairo in the years since. To facilitate an initial overview of the parameters of the topic and directions for further study, the project adopted several qualitative methods. 
In twenty-four in-person, semi-structured, in-depth interviews, recorded and transcribed, participants were asked for their assessments of local dynamics and capacities. Trained interpreters assisted in around half of the interviews. The interview schedule contained open-ended questions on the content, channels, and efficacy of current information about asylum in Cairo, the development of communication and information strategies, and participant estimates of literacy and of mobile and web use prevalence.

Participants were selected based on their professional and personal experience in refugee service provision and selfassistance in Cairo. Contacted through personal networks as well as UNHCR Cairo's 2011 Referral Guide for Refugees and Refugee Service Providers, nine participants worked in service providing organizations (SPOs), including UNHCR, and fifteen were refugees, thirteen of whom were affiliated with community-based organizations (CBOs) from the major national groups in Cairo (Sudanese, Somali, Iraqi, Eritrean, Ethiopian). ${ }^{29}$ The research is thus limited, most notably by the absence of input from Egyptian government officials, who I was unable to reach in the interview stage.

The research additionally draws from field notes from informal conversations with researchers, service providers, and refugees in Cairo, and participant observation in Cairo 2005-6 and 2010-12 in workshops, seminars, and events related to the topic at hand. The project also reviewed relevant published and unpublished reports (some provided by research participants), online sources, and UNHCR documents related to communication and outreach with urban refugee and asylum seeker populations. This included study of "shelved" communication projects to learn how previous plans had been conceived, what had been learned in their development, and why they failed.

Drawing from this pilot research, the following findings offer an initial view into dynamics of communication in refugee protection and services in Cairo, bringing attention to uses and potentials around information and communication technologies in the urban asylum context.

\section{Project Findings}

Communication about Asylum in Cairo:

Role and Impacts

To frame its study of information and communication technologies in asylum in Cairo, the research examined the broader role of communication between service providers and refugee communities in Cairo. As this section reviews, such outreach has had access, protection, and psychosocial impacts, both in emergency situations like the 2005 protest and 2011 revolution, and in times of relative stability. It has been repeatedly been identified as a critical issue by those involved with refugee protection in Cairo.

Asylum in Cairo became world news in 2005, when several thousand Sudanese forced migrants ${ }^{30}$ staged a sit-in for three months in front of UNHCR's Cairo office. Although the demonstration had its roots in multiple problems faced by Sudanese in Egypt, ${ }^{31}$ its high numbers were also due at least in part to rumours about the benefits of joining in. ${ }^{32}$ During the sit-in, UNHCR Cairo closed its doors, so asylum seekers newly arrived in Cairo remained unregistered and at risk of imprisonment and refoulement.

The 2005 protest brought multiple communication issues to light: inaccessibility of information about the rules and rights of asylum, mutual distrust between refugees and UNHCR, a spiralling rumour mill, and a "fortress mentality" from the office. ${ }^{33}$ In an interview on the event, Barbara Harrell-Bond, who taught at the American University in Cairo at the time, stated, "What the protest symbolises is the total breakdown of communications between the UNHCR and the refugees." 34

The event became known as a "tragedy of failures and false expectations" 35 - expectations formed by its participants in part due to a "lack of understanding on what UNHCR can and cannot do." 36 In its report on the protest, UNHCR Cairo acknowledged its "lack of dialogue" with refugees and the "need to enhance the availability and dissemination of credible information." 37 Following a brutal forced eviction by police, in which at least twenty-seven protest participants were killed, the absence of communication channels between service providers and refugees impeded the task of tracking, reuniting, and assisting the injured, arrested, and missing.

The 2011 revolution became another crisis of communication for service providers and refugee communities in Cairo. Mobility within the city became dangerous and tightly restricted by soldiers and neighbourhood patrols. The government cut off Internet and mobile phone networks for five days of the uprising. UNHCR and many of its partners closed their offices, with some staff evacuated and others working from home. Refugees could not access their jobs, services, cash assistance, or subsidized health care. The ignorance of soldiers about the special legal status of refugees resulted in at least 133 arrests. ${ }^{38}$

The UNHCR office reopened to a series of protests by refugees angered by what they felt was their abandonment during the crisis. ${ }^{39}$ Efforts by high-ranking officials to address their concerns through face-to-face meetings intended to deliver information to the broader community were marred by difficulty finding representative messengers. The following months would see groups from Cairo's major refugee communities staging multiple demonstrations for 
assistance and attention, resulting in several periods of closure of the UNHCR office over 2011. ${ }^{40}$

The 2005 demonstration and 2011 revolution and subsequent political turmoil illustrate both the important role of communication between service providers and refugee communities in Cairo, and its complex and emotional nature. The problems faced by forced migrants in the crises were multiplex and driven by major contextual factors. Yet in both, communication failures in particular impacted the access, safety, and well-being of both service providers and forced migrants.

The pilot project found such impacts evident in times of stability as well as in emergencies. First, limited distribution of information about the range of services for forced migrants in Cairo impacts access to services. An indicative example is the 2009 survey research commissioned by UNHCR into refugee livelihoods in Egypt that found that "refugees and asylum seekers lack information about most of the vocational training programs targeting them." 41 This issue is not unique to asylum in Cairo; lack of information has been shown to be a barrier to refugee service access in multiple urban contexts around the world. ${ }^{42}$

Second, problematic outreach to refugee communities has direct outcomes for protection. The crises described above showed that, unabated, communication problems can disrupt the functioning of service providers, with protests leading to office closures that leave both newly arrived asylum seekers and Cairo resident forced migrants without access to protection. Closures can also slow the processing of RSD procedures, resulting in delayed recognition and protection. Communication has also played a role in the physical safety of refugees: both past and ongoing protests have resulted in arrests and imprisonment. During the revolution, communication might have helped prevent army arrest of refugees and asylum seekers on the basis of ignorance about UNHCR identity cards. More indirectly, communication failures around the 2005 protest contributed to the actual injury and deaths of Sudanese men, women, and children.

Communication's role in protection emerged in studies of asylum in Cairo as early as 2002. UNHCR Cairo acknowledged that misinformation had become an obstacle to protection as the circulation of rumours in refugee communities undermined applicant confidence in the refugee status determination (RSD) process and led to a decrease in recognition rates. ${ }^{43} \mathrm{~A}$ lack of information provision from the UNHCR side exacerbated this problem. Asylum seekers reported that they had "difficulty obtaining routine information from UNHCR Cairo about the status of their applications," were "unable to ask simple questions of UNHCR about procedures," and even were "refused at the UNHCR-Cairo gate when trying to submit requests or inquiries in writing." ${ }^{4}$ This inaccessibility was, not surprisingly, "a source of frustration and anxiety for applicants."45

Such emotional responses comprise a third impactpsychosocial-of communication about asylum. This consequence is particularly evident with regard to information about resettlement in Cairo, a lack of which may create "extreme distress" for some refugees. ${ }^{46}$ The rules surrounding resettlement-a goal of many forced migrants in Cairoare complex and opaque. Resettlement processes are long and undefined, entailing coordination between multiple local and international bodies, all of which have their own sets of checks, processes, and screenings. An Iraqi refugee research participant described the stasis of not knowing the status of his resettlement case as "truly a slow death, because you are waiting and waiting and waiting." The incidents described above also show how withheld or limited information can contribute to mistrust, anger, and stress in the individuals involved.

\section{Channels of Outreach: Uses}

Having argued that communication between service providers and refugees plays a significant role in how forced migrants experience and access assistance and protection in Cairo, this paper turns to review the channels used in current outreach. The pilot research found evidence of slow but positive expansion of strategies for communication and the distribution of information to refugee communities in Cairo.

Though refugee communities and service providers are spread throughout greater Cairo, in-person, site-specific communication remains the primary medium for asylum information delivery in the city, through individual case management, community meetings and workshops, and formal and informal outreach work by refugees and service providers. Research participants reported that its increase in recent years has improved the circulation of accurate information and in some cases helped address the concerns of people protesting at UNHCR.

Refugees who have formed community-based organizations or are employed by service providers often spread information informally as well, as they become known as trusted and knowledgeable in their communities. The offices of community-based organizations and businesses catering to refugee communities-restaurants, cafes, bakeries-are additional key sites of in-person information sharing.

Service providers use several kinds of printed material to link refugees with information about asylum in Cairo: distributed letters, posted results listings, information booklets, posters, and occasional brochures. The majority of printed information about asylum in the city is either 
site-specific, like printed notices and letters posted in offices and businesses frequented by refugees and asylum seekers, or lengthy, with limited distribution.

Sometimes, such as in the aftermath of the 2011 revolution, or when a major office has an emergency closure, UNHCR and other major service providers send announcements in the form of letters attached to emails, usually in Arabic and English, for community-based organizations and service providers to print and post. UNHCR uses the same method to distribute lists of results of the status of individual RSD cases, which refugees can then view posted at service provider locations. Some service providers use posters to publicize details of their services or programs at their offices.

More in-depth information about asylum in Cairo takes the form of printed booklets. One is an annual 96-page listing of service-providing organizations in the city. This directory is comprehensive and useful, but published only in English and Arabic and limited in distribution. Two refugee research participants who work at service providing organizations had not seen it before their interview for this project. A 47-page booklet published by another service provider reviews refugee status determination procedures, frequent legal problems, psychosocial and health services available in Cairo, information for unaccompanied children and young people, sexual and gender based violence in Egypt, and the resettlement process and programs. It is published in the languages of Cairo's five predominant refugee communities and distributed at the organization's office and by community outreach workers. ${ }^{47}$

A more accessible form of print is the short brochure used by another service organization. A single, thick, fullcolour page folded into three panels, an envelope is affixed to the central panel which contains the appointment time of each refugee who applies for the service. The brochure is printed with the details and requirements of the services in simple, clear language (albeit only in English and Arabic). Physically linking the appointment slip with the brochure ensures that each client receives the same essential information about the service.

Service provider use of two telephone channels to provide information to refugees in Cairo has begun to expand. Following the 2011 revolution, UNHCR introduced a phone hotline by which refugees and asylum seekers can make inquiries and appointments in their native language-services previously only accessible in person.

One Cairo service provider has introduced the use of group text messaging (also known as Short Message Service, SMS), both for reaching its beneficiaries and for contacting potential newly registered asylum seekers, whose names and numbers they get from UNHCR. The SPO subscribes to a group text service with mobile company Vodafone that provides computer software allowing them to easily send out announcements on a mass scale. The SPO also uses SMS to reschedule appointments and to remind beneficiaries to bring in certain documents, of timing of activities, or to renew their membership cards. Seeing the success of the system, other service providers have begun to adopt it.

Service provider use of websites, email, and social media to reach refugee communities in Cairo is mixed but generally limited. The majority of Cairo's service provider organizations' websites are donor oriented, describing their work much in the style of an annual report. Although this was previously the case for UNHCR Cairo, the office has recently updated their site to include its address, hours, email address, phone, fax, and location map, as well as a complete directory of their partners' organizations. At least one service provider used to have a section of its website with information for refugees, but it is now under construction; one CBO contains a listing of SPOs and CBOs but is several years out of date. Many of Cairo's refugee services websites lack even basic information about how to find or contact the organization.

An organization that deals with resettlement has an online case tracking system, but provides minimal explanation and no timing estimates. A service provider said she has a client awaiting resettlement whose online profile has simply said "pending" for the past three years-an example that illustrates the importance of helpful content to the success of even new technologies.

Email is widely used in service providers and community based organizations for interagency communication and referrals. However, the service providers interviewed for the research said that email is a less effective channel for receiving queries from refugees. Incoming messages tend to be long and complex requests which would be better dealt with through an interpreter on the phone or in person. Outgoing email, on the other hand, has been productive. As noted earlier, service providers use email to widely distribute notices in multiple languages for further oral or print dissemination.

\section{Channels of Outreach: Considerations for Development}

The pilot research considered evidence of interest in the development of outreach practices in light of both relevant features of Cairo's refugee populations and the city itself. This section reviews these findings in order to consider differentials in efficacy of channels and approaches chosen for outreach to refugee communities.

First, Egypt's heterogeneous refugee communities represent a shifting range of nationalities, languages, and education and literacy levels. At the time of the pilot study, 
refugees and asylum seekers in Egypt originated from Sudan, Iraq, Somali, Eritrea, Ethiopia, Syria, and other countries. ${ }^{48}$ An initial study with refugees in Cairo from six sub-Saharan African countries documented over thirty first languages and dialects. ${ }^{49}$ People from linguistically diverse Sudan form the majority of Cairo's refugees and speak a range of languages and dialects. Even the differing kinds of Arabic spoken (including Sudanese, Fur, Egyptian, Iraqi) can pose significant problems of communication between them. Furthermore, some refugees for whom Arabic is not a mother tongue reject the learning of Egyptian Arabic. ${ }^{50}$ The pilot research found misunderstandings due to language diversity to have been a major barrier to effective communication between service providers and refugee communities. ${ }^{51}$

Levels of education and literacy in Cairo's refugee communities also vary significantly. Participants in the pilot research reported mixed education and literacy levels in their communities, and amongst those who accessed their services. A 2009 UNHCR survey of 376 Sudanese, Iraqi, Somali, and Ethiopian refugees and asylum seekers provides a more systematic view: 38 percent of those surveyed had attended or completed technical or university education, 29 percent had attended or completed secondary education, 10 percent had attended or completed primary school, and 22 percent had not received formal education. Of those surveyed, 15 percent had very limited literacy. ${ }^{52}$ This suggests the need for outreach to tailor to a range of literacy levels.

Second, the urban setting makes travel to offices difficult for intersecting reasons, including cost of transportation, long travel times, incompatible working hours, and insecurity (as it does for refugees accessing services in Nairobi, Kenya). ${ }^{53}$ Given the city's notorious crowding and traffic, travel by minibus, bus, taxi, or the metro rail system pose considerable levels of cost, time, and hassle. The hardship of travel can be exacerbated by long wait times at service provider offices. Travel across Cairo can be difficult or impossible for the elderly, chronically ill, or those with physical disabilities, and can pose safety issues. Visible minorities, especially sub-Saharan Africans, face public discrimination, harassment, and abuse. Since the 2011 revolution, increased street crime has disproportionally impacted minorities in poor areas, and civil unrest has resulted in frequent and unpredictable disruptions of transport as well as office closures. One service provider interviewed called the need for travel to access information services "a great burden," stating that "it's really getting on refugees' nerves, because they deal with so many entities, different services." Stress in the experience of accessing services can build resentment that can become a communication barrier in itself.
Third, initial evidence suggests widespread use of mobile phones and growing use of the Internet by forced migrants in Cairo. In a survey made by an Iraqi refugee in 2007 of 1,320 Iraqi refugees in Egypt, 99 percent said they could be reached by mobile phone. ${ }^{54}$ Pilot research participants were unanimous in their assessment that the majority of refugees and asylum seekers in Cairo use mobile phones, using phrases like "everyone" and "everybody" to describe how many have mobiles.

The pilot research found the Internet to play a significant role in Cairo's refugee communities. In a 2006 survey of 162 refugees and asylum seekers of various nationalities, distributed at SPOs and CBOs in Cairo, 152 (94 percent) reported that they used the Internet. Ninety-six of those surveyed said they accessed it in Internet cafes, twenty-six at home, nine at home or a cafe, and five at their workplace. ${ }^{55}$ In a 2007 survey of 1,320 Iraqis, 86 percent said they could be reached by email or social networking sites. ${ }^{56}$ In both surveys, the participant selection was non-probabilistic and convenience-based, so may not be generalized, but is nonetheless indicative.

Refugee research participants said that although most in their communities do not own personal computers, many nonetheless access the Internet through Cairo's many Internet cafes, and at service provider and community based organizations that have computers for public use, at least one of which offered computer classes as early as 2005. Others share computers, or rely on others for webbased information. An Iraqi refugee estimated that amongst Iraqis in Cairo, "there is one in each family who can use computers." A Somali research participant reported that Somali youth relay online information to their older family members. Computer sharing thus also helps overcome varying levels of literacy, language acquisition, and computer literacy within households. Another trend indicated in research interviews was a prevalence of social media use, which is burgeoning in refugee communities in Cairo, especially amongst young people.

\section{Developing Urban Refugee Outreach: Interest and Ideas}

The diversity of Cairo's refugee communities, difficulty of transport, and indications of rising use of new information and communication technologies in refugee communities suggest the importance of the expansion of existing outreach practices. The pilot research solicited participant assessments of the benefits, limits, and ideas for this development. This section considers potential channels in turn, demonstrating caveats and capacities in technologies old and new to improve information and communication about urban asylum. 
The study found site-specific communication to be considered a cornerstone of good information provision in the city, whether at offices or through neighbourhood visits. Provided that an interpreter is present if needed, oral communication can allow service providers to explain, discuss, and respond to queries in a way that tailors to the specific needs of the individual or group present. It may also foster relationships and trust.

The employment of refugee outreach workers has been a key element. One organization has formed specifically to train and place refugee psychosocial workers in organizations and communities throughout the city. These employees travel into neighbourhoods, pass out their mobile number, and invite co-nationals to workshops and meetings. This approach was credited by several research participants as being the biggest single improvement in the regular spread of accurate information amongst refugee communities in Cairo.

The research found interest in the use of office waiting rooms to reach out during waiting times, through posters, brochures, or video-a site-specific medium which could bypass literacy barriers and, if offered in multiple languages, language difference.

Despite such potentials, however, site-specific information provision has drawbacks. It can disadvantage newly arrived asylum seekers who do not know where to find information, and those with few social ties. Messages spread within communities by word of mouth are often distorted in the process, and misinformation and rumours have often spread within Cairo's refugee communities as a result.

The utility of printed material depends on its distribution and the extent to which it addresses the diversity of languages and literacy rates in Cairo's refugee communities. Long and complicated documents were cited by multiple research participants as a problematic technology, and the use of short, simple, easy-to-distribute brochures and flyers is not common in Cairo. Yet expanded use of printed materials could offer a way to reach people who, for whatever reason, do not or are unable to make office visits or seldom attend events for refugees.

Several research participants suggested increased use of cartoons and comics developed with refugee input, to increase comprehension and efficacy of the documents being distributed. One program that gives a short, clear brochure to all who access its services reports unanimously positive feedback, whereas previously, program requirements were explained only orally and therefore vulnerable to misinterpretation or inconsistency between staff members.

One participant suggested that each service provision organization in Cairo have a short flier or brochure that briefly describes how to access their services. During discussions in regular interagency meetings, participants could stuff bags or envelopes with brochures which could then be further distributed at events and offices and easily passed along from person to person.

SMS and phone hotline programs are logical matches to widespread mobile phone use in refugee communities in Cairo. These two phone uses serve quite different purposes, but were each unanimously supported by both refugee and service provider research participants.

All participants spoke of the SMS system's success. An employee of the organization said that the system has "impacted on the relationship between staff and refugees when they are in the office. It really has improved." An Iraqi refugee said that his mother, who receives services from the SPO, has benefited from the text message system: "She doesn't need to go to [the SPO] every month to check when is the day of payroll. She receives the message every month, and they tell her the exact time to receive the money." One pointed out SMS's ability not only to instantly transfer information, but to provide a record of that transfer, and to be a resource that its recipients can consult repeatedly.

A telephone hotline established after the revolution has been another appreciated initiative, as a Somali participant commented: "I think it's a very good step forward. It saves cost, it saves time." He also noted that a friend had successfully made an appointment through the hotline in his native tongue. An Iraqi participant stated: "Phone numbers, texting, giving refugees more attention than they are giving now, it's one of the good things, good intentions that they could show to refugees, that 'We are taking care of you, we are giving you care, we are trying." Communication efforts that harness multiple channels thus also convey effort and respect.

Some service providers seem to underestimate refugee use of the Internet and neglect it as a channel of contact. Yet research participants unanimously supported increased use of the Internet to provide information about asylum for refugees. Their suggestions included user-friendly, multilingual websites, ${ }^{57}$ online video, photographs and drawings, downloadable audio podcasts, and use of social media. Service providers suggested that current print information be provided online as well, with each organization given access in order to keep contact and service information up to date-information that could then also be downloaded, printed, and further distributed.

In the past years, several initiatives were launched by refugees and service providers to build informative websites, phone hotlines, and web forums for Cairo-based refugees. In the projects' initial phases, which included surveys, focus groups, and content development, both projects received strong community support and positive feedback. However, 
those involved in their creation lacked institutional support or external funding to move the projects forward, and they have not come to fruition.

\section{Conclusion}

This article explored the role of information in urban asylum, and current and possible uses of technologies to facilitate urban refugees' access to needed information, services, and protection. Pilot research into communication about asylum in Cairo found it to play a serious role in access, protection, and the experiences and relationships between forced migrants and service providers. To address existing needs, questions, and misunderstandings, the content of information strategies should thus be refugee-centred. In Cairo, this includes publicizing services, addressing the need for estimates for wait times regarding RSD and resettlement processes, and more generally clarifying procedures, limits, and responsibilities vis-à-vis resettlement, rights, and benefits.

Service providers increasingly share information about asylum through face-to-face, printed, phone, and online channels. The linguistic and literacy diversity of forced migrants in Cairo, the difficulty of transit in the city, and indications of rising use of new information and communication technologies in refugee communities all suggest the importance of the expansion and development of existing outreach practices. Passive forms of information can overcome constraints of site-specific and oral communication, especially if multiple channels are used simultaneously, updated regularly, and designed with content in multiple languages and media in order to be accessible across Cairo's diverse refugee communities.

The urban setting's challenges make the expansion and institutionalization of good communication practices for refugees in cities particularly important. The project of communicating with urban refugee populations should receive more funding and attention from donors, governments, and international organizations. International philanthropic and corporate interest in ICT's use for social problems ought to be harnessed to support existing and future locally led initiatives that are designed with the participation of refugees. Service providers and refugees have made efforts in this direction but lack the required time, funds, and institutional support to make them sustainable. Further research is also needed into how refugees learn about and discuss asylum, and how the use of websites and social media to link refugee communities with information about asylum might best be developed.

Communication cannot overcome the substantial contextual barriers to asylum in Cairo, but it has the potential to mitigate their effects. Information delivery that conveniences and addresses the needs of refugee communities can strengthen protection, improve access to services, and ease refugees' experiences of asylum in the city. In the growing study of technology's role in the lives of refugees, this paper highlights the continued need to consider how intersecting geopolitical and technological contexts impact upon asylum, and to include attention to the particular experiences of forced migrants who live in cities in the global south.

\section{Notes}

1. This paper uses "refugee" and "asylum seeker" to refer to people recognized as such by UNHCR, with the knowledge that matters discussed could be relevant to a wider population of forced migrants. It uses "refugee communities" to refer to populations of people with mixed migratory and legal statuses who originate from refugee sending countries.

2. UNHCR, "2013 UNHCR country operations profileEgypt," UNHCR-Egypt website (2013), accessed June 30, 2013, http://www.unhcr.org/pages/49e486356.html. There are 50,000 to 70,000 Palestinians who also live in Egypt, under the care of the United Nations Relief and Works Agency for Palestine Refugees in the Near East (UNRWA) rather than UNHCR. See Oroub El-Abed, "The Palestinians in Egypt: Identity, Basic Rights and Host State Policies," Refugee Survey Quarterly 28, no. 2-3 (2009): 531-549.

3. As of June 2013, 1,250 refugees and asylum seekers remain in Saloum. See UNHCR, "Depression grips forgotten refugees stranded at Egyptian-Libyan border," UNHCR website-News Stories (2013), accessed June 30, 2013, http:// www.unhcr.org/51cad70f9.html.

4. For an innovative mapping of residence patterns of Sudanese in Cairo, see Karen Jacobsen, Maysa Ayoub, and Alice Johnson, "Remittances to Transit Countries: The Impact of Sudanese Refugee Livelihoods in Cairo," Cairo Studies on Migration and Refugees 3 (2012): 16-18, accessed October 30, 2012, http://www.aucegypt.edu/GAPP/cmrs/reports /Documents/paper\%20No.\%203.pdf.

5. At time of publication, these included a growing population of Syrians, as well as new arrivals seeking asylum from Sudan and South Sudan. For current statistics, see UNHCR, "2013 UNHCR country operations profile."

6. Martin Jones, "We Are Not All Egyptian," Forced Migration Review 39 (2012): 16; Jacobsen, Ayoub, and Johnson, "Remittances to Transit Countries," 28, 36-39; and Michael Kagan, "Shared Responsibility in a New Egypt: A Strategy for Refugee Protection" (working paper, Center for Migration and Refugee Studies, American University in Cairo, 2011): 4

7. Jones, "We Are Not All Egyptian," 16; Jacobsen, Ayoub, and Johnson, "Remittances to Transit Countries," 21, 28, 36-39; Zehra Rizvi and Dale Buscher, "Shifting Sands: Risk and Resilience among Refugee Youth in Cairo," Women's 
Refugee Commission (2012): 6, accessed November 20,2012, http://womensrefugeecommission.org/resources/doc_ download/858-shifting-sands-risk-and-resilience-among -refugee-youth-in-cairo.

7. Kagan, "Shared Responsibility in a New Egypt," 11.

8. See Fateh Azzam, ed., "A Tragedy of Failures and False Expectations: Report on the Events Surrounding the ThreeMonth Sit-In and Forced Removal of Sudanese Refugees in Cairo, September-December 2005” (Report, Forced Migration and Refugee Studies, American University in Cairo, 2006): 9.

9. Ibid., 18-19; Ray Jureidini, "Irregular Workers in Egypt: Migrant and Refugee Domestic Workers," International Journal on Multicultural Societies 11 (2009): 75-90; Dale Buscher and Lauren Heller, "Desperate Lives: Urban Refugee Women in Malaysia and Egypt," Forced Migration Review 34 (2010): 20-1; Rizvi and Buscher, "Shifting Sands," $1,9$.

10. Elzbieta Gozdziak and Alissa Walter, "Urban Refugees in Cairo," Institute for the Study of International Migration (2012): 17, accessed November 22, 2012, http://issuu.com/ georgetownsfs/docs/urban_refugees_in_cairo/1; Jacobsen, Ayoub, and Johnson, "Remittances to Transit Countries," 28.

11. See Emily Eidenier, "Providing Health Care Information to Refugees in Cairo: Questions of Access and Integration" (Report, Forced Migration and Refugee Studies, American University in Cairo, 2006), accessed March 2, 2012, http://www.aucegypt.edu/GAPP/cmrs/reports/Documents/Eidenier.pdf; Marisa Ensor, "Education and SelfReliance in Egypt," Forced Migration Review 34 (2010): 25-6; and Sarah Hodgson, "Psychosocial Well-Being within Refugee Education in Cairo," Fahamu Refugee Legal Aid Newsletter (June 2013), accessed June 4, 2013, http://frlan.tumblr.com/post/51869692799/psychosocial -well-being-within-refugee-education-in.

12. Kagan, "Shared Responsibility in a New Egypt," 5.

13. See Azzam, "A Tragedy of Failures; Nora Danielson, "Field Report: Revolution, Its Aftermath, and Access to Information for Refugees in Cairo," Oxford Monitor of Forced Migration 2 (2012): 57-63. Following the killing of at least twenty-eight Sudanese protesters at the end of a threemonth long sit-in in front of UNHCR Cairo in 2005, growing numbers of forced migrants left Cairo to seek asylum in Israel. This trend subsided, however, following multiple instances in which Egyptian border security shot and killed those attempting to cross into Israel; ongoing cases of kidnapping, extortion, and torture by traffickers in the Sinai; and harsh measures towards asylum seekers taken in Israel. The Sinai remains a site of unhindered human rights violations in human trafficking from Eritrea and Sudan. See Human Rights Watch, "Sinai Perils: Risks to Migrants, Refugees and Asylum Seekers in Egypt and Israel," Human Rights Watch (2008), accessed March 13, 2011, http://www .hrw.org/sites/default/files/reports/egypt1108webwcover .pdf; Rebecca Furst-Nichols and Karen Jacobsen, "African Refugees in Israel," Forced Migration Review 37 (2011): 55-6; and Rachel Humphris, "Refugees and the Rashaida: Human Smuggling and Trafficking from Eritrea to Sudan and Egypt," New Issues in Refugee Research 254 (2013): 4.

14. Katarzyna Grabska, "A System of Diffuse Responsibility, With Blame Shared by All," RSDWatch (2006), accessed October 2, 2010, http://rsdwatch.wordpress .com/2006/06/16/forum-the-lessons-of-cairo-a-system-of -diffuse-responsibility-with-blame-shared-by-all/.

15. See Kagan, "Shared Responsibility in a New Egypt," 9-20, for a more detailed overview of refugee protection in Egypt.

16. At time of publication, the total "population of concern" to UNHCR Egypt was 126,949 people. Of these, 109,933 held refugee status, 16,952 were asylum seekers, and 60 were stateless. UNHCR, "2013 UNHCR country operations profile."

17. UNHCR, The State of the World's Refugees (Oxford: Oxford University Press, 2012).

18. See for example Noel Calhoun, "UNHCR and Community Development: A Weak Link in the Chain of Refugee Protection?" New Issues in Refugee Research 191 (2010); Tania Kaiser, "Participation or Consultation? Reflections on a 'Beneficiary Based' Evaluation of UNHCR's Programme for Sierra Leonean and Liberian Refugees in Guinea, JuneJuly 2000," Journal of Refugee Studies 17, no. 2 (2004); Terry Rempel, "UNRWA and the Palestine Refugees: A Genealogy of 'Participatory' Development," Refugee Survey Quarterly 28, no. 2 \& 3 (2010): 412-437; Roxane Wilber, "Leveraging Women's Community Leadership: A Model for Outreach in Urban Refugee Populations" (Institute for Inclusive Security publication, 2011), accessed April 22, 2011, http://www.inclusivesecurity.org/wp-content/ uploads/2013/05/Urban-Refugees_FINAL.pdf.

19. See for example Larry Bottinick and Areti Sianni, "No Place to Stay: A Review of the Implementation of UNHCR's Urban Refugee Policy in Bulgaria" (UNHCR Policy Development and Evaluation Service Evaluation Report 2011/04, 2011); Angela A. L. Rosi, Marco Formisano, and Ljubo Jandrijasevic, "Lives in Limbo: A Review of the Implementation of UNHCR's Urban Refugee Policy in Tajikistan," (UNHCR Policy Development and Evaluation Service Evaluation Report 2011/03, 2011).

20. UNHCR, UNHCR Policy on Refugee Protection and Solutions in Urban Areas (2009), accessed April 3, 2012, http:// www.unhcr.org/refworld/docid/4ab8e7f72.html.

21. Tim Morris, "Selected Bibliography: Displacement to Urban Areas," UNHCR Online (2011), accessed June 5, 2011, http://www.unhcr.org/4b0ba1209.html.

22. Elizabeth Campbell, "Age, Gender, Diversity Mainstreaming Initiative Key to Urban Protection," Refugees International (2010), accessed April 15, 2011, http://www .refugeesinternational.org/print/4501; Karine Le Roch, Emmanuelle Pons, Jason Squire, Josephine Anthoine-Milhomme, and Yann Colliou, "Two Psychosocial Approaches 
for Iraqi Urban Refugees in Jordan and Lebanon: CenterBased Services Compared to Community-Outreach Services," Journal of Muslim Mental Health 5 (2010): 99-119.

23. Linda Leung, "Phoning Home," Forced Migration Review 38: (2011): 24; Linda Leung, "Taking Refuge in Technology: Communication Practices in Refugee Camps and Immigration Detention," New Issues in Refugee Research 202 (2011); Linda Leung, Cath Finney Lamb, and Liz Emrys, “Technology's Refuge: The Use of Technology by Asylum Seekers and Refugees" (Sydney: UTS ePress, 2009); Anastasia Panagakos and Heather Horst, "Return to Cyberia: Technology and the Social Worlds of Transnational Migrants," Global Networks 6, no. 2 (2006): 109-124; Manuela Prejato, and Alfonso Molina, "La Tecnologia Digitale Come Strumento Di Integrazione Per I Rifugiati," in La Tecnologia Digitale Come Strumento Di Integrazione Per I Rifugiati (Rome: Fondazione Mondo Digitale, 2010).

24. Mette M. L. Berg, "Conference Report: Digital Diasporas," Anthropology Today 27, no. 2 (2011): 28; Victoria Bernal, "Diaspora, Cyberspace and Political Imagination: The Eritrean Diaspora Online," Global Networks 6, no. 2 (2006): 161-179; Myria Georgiou, "Diasporic Communities OnLine: A Bottom-Up Experience of Transnationalism," Hommes Et Migration (London: London School of Economics, 2002).

25. See Antoine Bertout, Marc de Bourcy, and Mohammad Faisal, "Luxembourg-UNHCR-Skype Synergies," Forced Migration Review 38: (2011): 18-19, and others in Forced Migration Review 38; Caitlin Van Orden, "Community Technology Access: Bridging the Digital Divide for Refugees," The Blue Key Blog (2011), accessed May 30, 2011, http://bluekeyblog.org/blue-key/community-technology -access-bridging-the-digital-divide-for-refugees; UNHCR, "Q\&A: Former Bosnian Refugee Promotes Technology to Bring Hope to the Displaced," UNHCR News Stories (2010), accessed May 30, 2011, http://www.unhcr.org/ print/4ced313b6.html; UNHCR, "Community Technology Access," UNHCR Livelihoods \& Self-Reliance Website (2011), accessed May 30, 2011, http://www.unhcr.org/ pages/4ad2e8286.html; UNHCR, "Innovative Learning Methods and New Technology Assist Refugees Who Learn Ukranian: The UN Refugee Agency Equips Language Lab in Odesa International Humanitarian University," UNHCR Press Release (2011), accessed May 30, 2011, http://www .unhcr.org.ua/news.php?in=1\&news_id=206; UNHCR Regional Representation Bulgaria, "Launching the Community Technology Access Project for Refugees in Bulgaria," UNHCR Regional Representation Central Europe Facebook Webpage (2010), accessed May 27, 2011, http:// www.facebook.com/note.php?note_id=471850182846.

26. See for example Roger Zetter and George Deikun, "A New Strategy for Meeting Humanitarian Challenges in Urban Areas," Forced Migration Review 38 (2011): 48-50.

27. Azzam, "A Tragedy of Failures"; Emily Eidenier, "General project proposal: 'STAR website: information and communication for refugees and volunteers in Cairo"' (2006), on file with author.

28. To maintain participant confidentiality, both organizational and personal names of research participants have been anonymized.

29. The demonstrators were primarily UNHCR-recognized asylum seekers and refugees. Of the 2,174 surviving demonstrators arrested on the night of the eviction of the protest, all but 169 were eventually released from detention on the basis of being people of concern to UNHCR. Azzam, "A Tragedy of Failures," 23.

30. Nora Danielson, "A Contested Demonstration: Resistance, Negotiation and Transformation in the Cairo Sudanese Refugee Protest of 2005" (master's thesis, University of Oxford, 2008), on file with author.

31. UNHCR Regional Office Cairo, "Response to FMRS Report: 'A Tragedy of Failures and False Expectations"' (2006): 18-20, on file with author.

32. Azzam, "A Tragedy of Failures," 5, 16, 58-59.

33. Gamal Nkrumah, "Radical Refugees", Al-Ahram Weekly 769 (2005), accessed 6 November 2006, http://weekly .ahram.org.eg/2005/769/feature.htm.

34. Azzam, "A Tragedy of Failures."

35. UNHCR Regional Office Cairo (2006): 6.

36. Ibid., 26, 29.

37. Jones, "We Are Not All Egyptian," 16.

38. Mahmoud Farag, "Cairo Refugees and the Revolution" (Student Action for Refugees presentation, American University in Cairo, 23 March 2011), on file with author.

39. Jon Jensen, "For Refugees in Egypt, It's Worse," Shooting Egypt Blog (2011), accessed September 9, 2011, http:// jonjensen.com/blog/?p=1829\#more-1829.

40. Heba Moghaieb, "Strengthening Livelihood Capacities of Refugees and Asylum Seekers in Egypt," UNHCR Survey Report (2009): 30.

41. See for example Adam Saltsman, "Rumour versus Information," Forced Migration Review 26: (2010): 57-58; Adam Saltsman, "Displaced Iraqis in Jordan: Formal and Informal Information Flows, and Migratory Decisions in a Context of Uncertainty," Refuge 28 (2011): 81-96.

42. Michael Kagan, "Assessment of Refugee Status Determination Procedure at UNHCR's Cairo Office 2001-2002" (working paper, Forced Migration and Refugee Studies, American University in Cairo, 2002): 11, 12, 17.

43. Ibid., 20.

44. Ibid., 20.

45. Hala Mahmoud, "Disrupted Lives and Shattered Dreams: Culture, Identity, and Coping Pathways among Sudanese Refugees in Cairo" (PhD dissertation, Faculty of Politics, Psychology, Sociology, and International Studies, University of Cambridge, 2009): 3; Moghaieb, "Strengthening Livelihood Capacities," 30.

46. Since the pilot research a third booklet, 116 pages long, has been produced, which clearly presents comprehensive information on the rules and processes of asylum. At time 
of publication it was available in English and Arabic, with plans to translate it into other languages.

47. UNHCR RO-Cairo, UNHCR Egypt fact sheet, January 2012 (2012), accessed February 20, 2012 at http://www.unhcr .org/4f4c956c9.pdf. This number included some living in Alexandria and smaller towns in Egypt, and new asylum seekers who fled from the 2011 unrest in Libya to the border town of Saloum. The total did not include Palestinians living in Egypt, who do not receive assistance from UNHCR; people who had not sought recognition as refugees; people whose applications for refugee status had been rejected but continue living in Egypt; or some asylum seekers who passed through the Sinai in an attempt to reach Israel.

48. Daniele Calvani, "Initial Overview of the Linguistic Diversity of Refugee Communities in Cairo" (working paper, Forced Migration and Refugee Studies, American University in Cairo, 2003): 2-3, 9.

49. Ibid., 38.

50. Nora Danielson, "Urban Refugee Protection in Cairo: The Role of Communication, Information and Technology," New Issues in Refugee Research 236 (2012): 15-17.

51. Moghaieb, "Strengthening Livelihood Capacities," 14-15.

52. See Martin Anderson, "The Cost of Living: An Analysis of the Time and Money Spent by Refugees Accessing Services in Nairobi," New Issues in Refugee Research (2012), accessed March 30, 2012, http://www.unhcr.org/4f070ace9.pdf.

53. Email from research participant (2012), on file with author.
54. Eidenier, "Providing health care information."

55. Email from research participant (2012), on file with author.

56. A good model is the Australian website Asylum explained (Asylum Seeker Resource Centre 2012), which is offered in English, Arabic, Chinese (simplified and traditional), Dari, Sinhalese, Urdu, Bengali, Korean, Indonesian, Tamil, Vietnamese, Malay, Persian, Thai, and Hindi. The site lists contacts and resources, and covers the topics "What is 'seeking asylum' in Australia?"; "Am I a refugee?"; "How do I get protection?"; and "I arrived by boat" (available online, http://www.asylumexplained.asrc.org.au/).

57. Eidenier, "Providing health care information"; Helpline Egyptian for Asylum Seekers, Migrants and Refugees, "Final Report of HEAR's Activities" (2010), on file with author.

Nora Danielson holds an MPhil in migration studies from the University of Oxford, where she is a doctoral researcher in anthropology at the Centre on Migration, Policy and Society. This paper draws from research partially funded by UNHCR's Policy and Development and Evaluation Service (PDES) and is revised from a working paper written for its series New Issues in Refugee Research. The author wishes to thank PDES, as well as those who participated in the pilot research and commented on the working paper.

(C) Nora Danielson, 2013. This open-access work is licensed under a Creative Commons Attribution-NonCommercial 4.0 International License, which permits use, reproduction and distribution in any medium for non-commercial purposes, provided the original author(s) are credited and the original publication in Refuge: Canada's Journal on Refugees is cited. 